\title{
Universiteit
}

Leiden

The Netherlands

\section{Forced labour and rising fertility in colonial Indonesia}

Henley, D.E.F.

\section{Citation}

Henley, D. E. F. (2011). Forced labour and rising fertility in colonial Indonesia. Asian Population Studies, 7(1), 3-13. doi:10.1080/17441730.2011.544900

Version: $\quad$ Publisher's Version

License: $\quad$ Licensed under Article 25fa Copyright Act/Law (Amendment Taverne)

Downloaded from: https://hdl.handle.net/1887/3193467

Note: To cite this publication please use the final published version (if applicable). 


\section{FORCED LABOUR AND RISING FERTILITY IN COLONIAL INDONESIA}

\section{David Henley}

To cite this article: David Henley (2011) FORCED LABOUR AND RISING FERTILITY IN COLONIAL INDONESIA, Asian Population Studies, 7:1, 3-13

To link to this article: https://doi.org/10.1080/17441730.2011.544900

$$
\text { Published online: } 03 \text { Mar } 2011 .
$$

Submit your article to this journal $₫$

Џ Article views: 232

4 Citing articles: 1 View citing articles 5 


\title{
FORCED LABOUR AND RISING FERTILITY IN COLONIAL INDONESIA
}

\author{
David Henley
}

This paper presents empirical evidence to support the labour demand theory of rising reproductive fertility in colonial Indonesia. According to this theory, birth rates in nineteenth-century Java rose as a direct result of the labour burden imposed upon women and their children by the Cultivation System of compulsory labour services. The theory was conceived in the 1970s as a reaction against the assumption that rapid population growth in colonial Indonesia must have reflected improvements in economic and health conditions under Dutch rule. The difficulty of testing the labour demand theory empirically, together with its counterintuitive quality and its ideological origins, led it to be sceptically received. However, newly-assembled statistical data from Minahasa - one of the few areas outside Java where compulsory cultivation services were introduced in the nineteenth century - suggest that the theory is in fact correct. The existence of a positive link between labour demand and fertility helps explain not only the paradox of population growth without rapid economic growth or public health improvements in nineteenthcentury Java, but also the 'involutionary' cycle of agricultural intensification, population growth and impoverishment which seems to be a recurrent feature of Southeast Asian history.

KEYWORDS: Indonesia; history; women; labour; fertility; involution

[T]he demand for men, like that of any other commodity, necessarily regulates the production of men. (Adam Smith, An Inquiry into the Nature and Causes of the Wealth of Nations 1776/1976, p. 98)

It is an obvious truth [...] that population must always be kept down to the level of the means of subsistence. (Thomas Malthus, An Essay on the Principle of Population, 1798 1976, p. 15)

\section{Why Did the Cultivation System Cause Birth Rates to Rise? A Still-Born Controversy}

In his classic study of population growth and economic development in nineteenthcentury Java, Peter Boomgaard proved the existence of a remarkable association between the Cultivation System - a regime of compulsory export crop deliveries imposed on Javanese peasants by the colonial state from 1830 to 1870 - and high birth rates among Javanese women. When demographic and economic data for 19 different Javanese residencies over the period 1830-1880 were compared, a statistically significant positive correlation emerged between fertility rates and the percentage of the population subject to Cultivation System labour services (Boomgaard 1989, pp. 176, 186). 
The importance of this finding is not limited to the specific context of nineteenthcentury Java. It may in fact provide a vital clue to the whole puzzle of the modern population explosion, which, in Indonesia as elsewhere in the world, is known to have involved rising fertility as well as declining mortality (Henley 2006). What kind of clue it provides, however, depends on how we interpret Boomgaard's correlation in terms of causal process, and here there is a major unresolved difference of opinion which might have been expected to generate controversy, but which instead has up to now remained largely unacknowledged.

Boomgaard's own interpretation (1989, p. 197) was that his result reflected a positive response on the part of Javanese women to the growth of the non-agricultural sectors of the Javanese economy, generated by the Cultivation System, which created new economic opportunites with higher returns to labour'. New sources of income from commercial activities stimulated by increased agricultural production, particularly in the transport and handicraft sectors, 'enabled increasing numbers of people to marry earlier than they could have done if they had had to wait for a piece of land'. The additional income also encouraged women to reduce their use of various deliberate constraints on marital fertility in order to increase the number of children they would bear. These hitherto widely-practiced means of birth control included abortion and contraceptive manipulation of the uterus (Boomgaard 1989, pp. 194-195).

There is, however, an alternative way, not mentioned by Boomgaard, of explaining the observed correlation between high birth rates and Cultivation System labour services. The other potential explanation is that fertility was boosted not indirectly by the income which the System supplied, but directly by the labour which it demanded. Ben White $(1973$, p. 233) adumbrated this argument at the beginning of the 1970s by suggesting that Javanese parents had met the colonial authorities' demand for additional labour from each peasant household by altering the allocation of food within their families in such a way as to allow more of their children to survive. A few years later, anthropologists Jennifer and Paul Alexander (1979) proposed that the response to labour demand had worked not via the manipulation of infant mortaility, but via the relaxation of traditional fertility controls, including abortion, delayed marriage and prolonged breast-feeding.

Distancing himself from the calculating interpretation of reproductive behaviour implicit in his original argument, Paul Alexander $(1984,1986)$ later came to favour a modified version of the labour demand theory in which conscious agency was no longer involved. The 'increased participation of women in arduous and sustained work' under the Cultivation System, he now proposed, left them less time for breast-feeding and forced them to wean their children more quickly (Alexander 1986, p. 257). This led automatically to shorter intervals between successive pregnancies, partly because of reduced lactational amenorrhoea and partly due to a custom, well documented in modern Java, of avoiding sexual intercourse for as long as breast-feeding continues.

Hull (2001, p. 159) has not unfairly described Boomgaard's interpretation, in which fertility rose in enthusiastic response to economic opportunities created by colonialism, as 'diametrically opposed' to that of the Alexander's, in which the Dutch forcibly worked Javanese women into producing more children despite deteriorating economic conditions. That Boomgaard did not take the labour demand theory seriously had to do with the speculative character of the publications in which it had been proposed, and with the fact that no explicit contemporary evidence was available for reduced breast-feeding as a result of increased labour demands. Paul Alexander (1986, p. 259) had himself surmised that archival research was 'most unlikely to unearth accounts of such esoteric matters'. 
Particularly since some classic nineteenth-century accounts identify arduous female workloads precisely as a reason for low reproductive fertility in Indonesia (Raffles 1817/ 1978 , vol. I, p. 70; Wallace $1890 / 1987$, p. 70), it must also be said that at first sight the idea that Indonesian women bore more children if they worked harder has a certain implausibility about it.

Nevertheless the income supply and labour demand models remain equally compatible, in principle, with the statistical evidence produced by Boomgaard. The labour demand interpretation, indeed, is more parsimonious in that it offers a more direct explanation for the observed correlation between fertility levels and the proportion of households in each residency involved in the Cultivation System. In Boomgaard's reasoning the latter variable is no more than a surrogate for a third, implied factor, the availability of remunerative employment opportunities in the transport and handicraft sectors incidentally stimulated by the System.

\section{Labour Demand, Income Supply, and the Birth Rate: Evidence from Minahasa}

Against the backdrop of this sharp contradiction in the literature on fertility and the Cultivation System in Java, evidence from Minahasa (North Sulawesi) at the same period sheds valuable light on the relative importance of labour demand and income supply to fertility patterns under conditions of compulsory export crop cultivation. Minahasa is a compact, fertile volcanic region with an area of about 5000 square kilometres where between 1822 and 1899, most of the population was obliged to grow coffee for delivery to the colonial authorities.

An official report on economic conditions in Minahasa compiled by the civil servant A. C. J. Edeling in 1874 included an investigation into the numbers of children ever born, and still living, in more than 8500 households distributed over 14 specified districts (Edeling 1875). For most of these districts, the report also indicated the number of days per household per year spent on coffee cultivation. Plotting these two variables against each other in all cases for which both fertility and coffee labour figures are available, a clear positive association is revealed (Figure 1). Those districts subjected to the greatest burden of compulsory coffee cultivation also tended to be those in which women had borne the greatest number of children. The statistical correlation here is strong and there is little chance that it is accidental. A Spearman rank correlation test on the same data gives a correlation coefficient of 0.90 , which for this sample size is significant at the one per cent level.

Coffee deliveries in Minahasa, although compulsory, were paid for at a low fixed price by the state, so in principle, it might be possible to interpret this correlation in terms of income supply rather than labour demand. The income earned from coffee cultivation, however, was not proportional to the time spent on it, and when average coffee earnings in the years 1873-1874 (also included in the Edeling report) are plotted against the results of the fertility survey for all districts for which both figures are available, no significant correlation emerges (Figure 2).

Non-agricultural employment opportunities associated with the compulsory deliveries, which as in Java were significant in the transport sector (Graafland 1867-1869, vol. II, p. 114; Quarles van Ufford 1856, p. 23), cannot be taken into account here. However, their distribution over the districts was probably similar to that of the coffee payments 


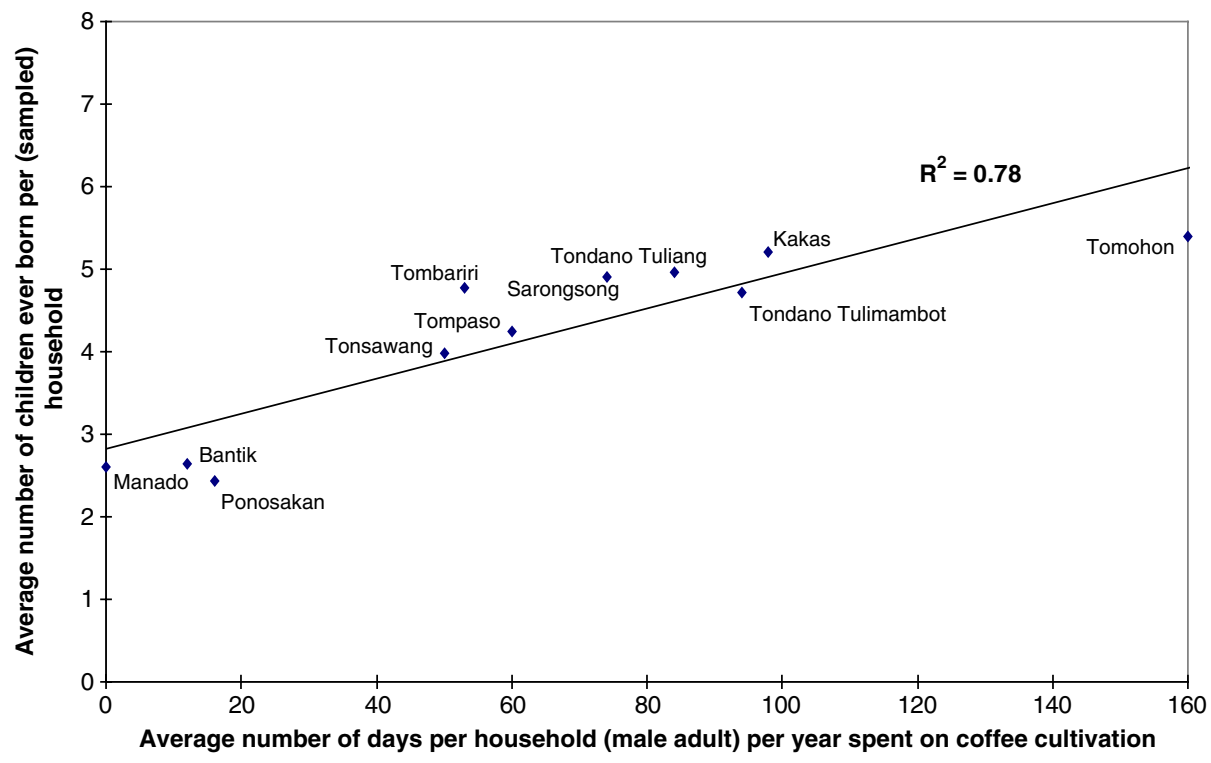

\section{FIGURE 1}

Female fertility and the burden of compulsory coffee cultivation in some Minahasan districts, 1874 (Henley 2005a, p. 387).

themselves, making it highly unlikely that a more complete income analysis could provide a more satisfactory explanation than labour demand for the local variations in fertility revealed by the Edeling survey. As far as the cultivation services themselves are concerned,

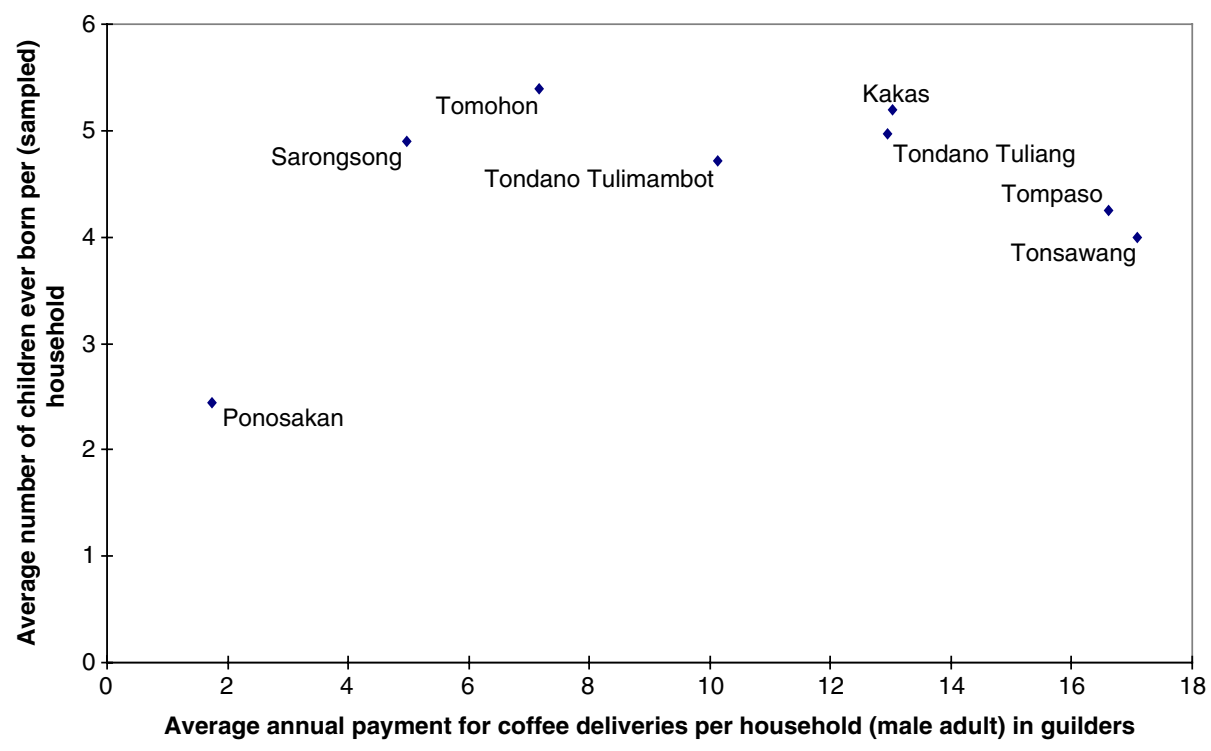

FIGURE 2

Female fertility and income from compulsory coffee cultivation in some Minahasan districts, 1873-1874 (Henley 2005a, p. 395). 
the Minahasan evidence is in any case clear: these elicited higher fertility directly via the labour burden they imposed, not indirectly via the income they supplied.

\section{Explaining the Correlation between Labour Demand and Fertility}

It is not possible to say for certain exactly how the link between labour demand and fertility operated. One possibility might be that it involved the deliberate production of more children to share the labour burden in the most heavily burdened districts. All the methods of conscious fertility restriction described from Java, including abortion, contraceptive rotation of the uterus, and infanticide, are also documented from nineteenth-century Minahasa (De Clercq 1870, p. 133; Graafland 1867-1869, vol. I, pp. 173, 245). Also, since children and teenagers shared and reduced the compulsory coffee labour services nominally incumbent on each adult male (Francis 1860, p. 282; Wessels 1891, p. 145), there was in principle an incentive to exercise fertility control less often where the labour burden was heaviest.

An alternative explanation is that proposed for Java by Paul Alexander: that the burden imposed by cultivation services on women themselves caused them to breast-feed their children less often and wean infants more quickly, leading to shorter intervals between births. Certainly a substantial part of the compulsory labour burden in Minahasa was borne by women (Graafland 1898, vol. II, p. 250; Jansen 1861, p. 230). What is also certain is that despite Alexander's pessimism regarding the chances of finding direct contemporary evidence for reduced breast-feeding as a result of compulsory labour, Edeling (1875) states explicitly in his report that the heavy workload imposed on Minahasan women is 'one of the reasons why mothers do not have enough time to give their children their natural food'. Complaints about over-rapid weaning of infants can be found even in published sources on Minahasa from the same period (De Clercq 1891, p. 219; De Lange 1897, p. 686). They stand in sharp contrast to the observation by a Dutch visitor in the seventeenth century, long before the imposition of compulsory cultivation services, that Minahasans 'breast-feed their children for long periods' (Padtbrugge 1866, p. 327).

The remarkable precision of the correlation between fertility rates and the size of the coffee labour burden (Figure 1) arguably tells in favour of an explanation via reduced lactational amenorrhoea rather than via deliberate fertility control. Even in the unlikely case that the rate of conscious birth control was determined solely by economic considerations, it is hard to imagine that mothers could predict their future household labour needs with the kind of accuracy indicated by the data; an automatic, unconscious mechanism like reduced breast-feeding would seem much more capable of accounting for such a close relationship. Given that infant mortality would presumably have been taken into account in any conscious calculation of the costs and benefits of childbearing in relation to a target household size, it is perhaps significant that according to the Edeling data the correlation between actual household size (numbers of surviving children) and the coffee labour burden, while still good, is not as good as that obtained using the total numbers of children ever born (Figure 3).

The evidence from nineteenth-century Minahasa, to sum up, provides support not only for the labour demand interpretation (as opposed to the income supply interpretation) of the association between compulsory labour and high fertility, but also for the 


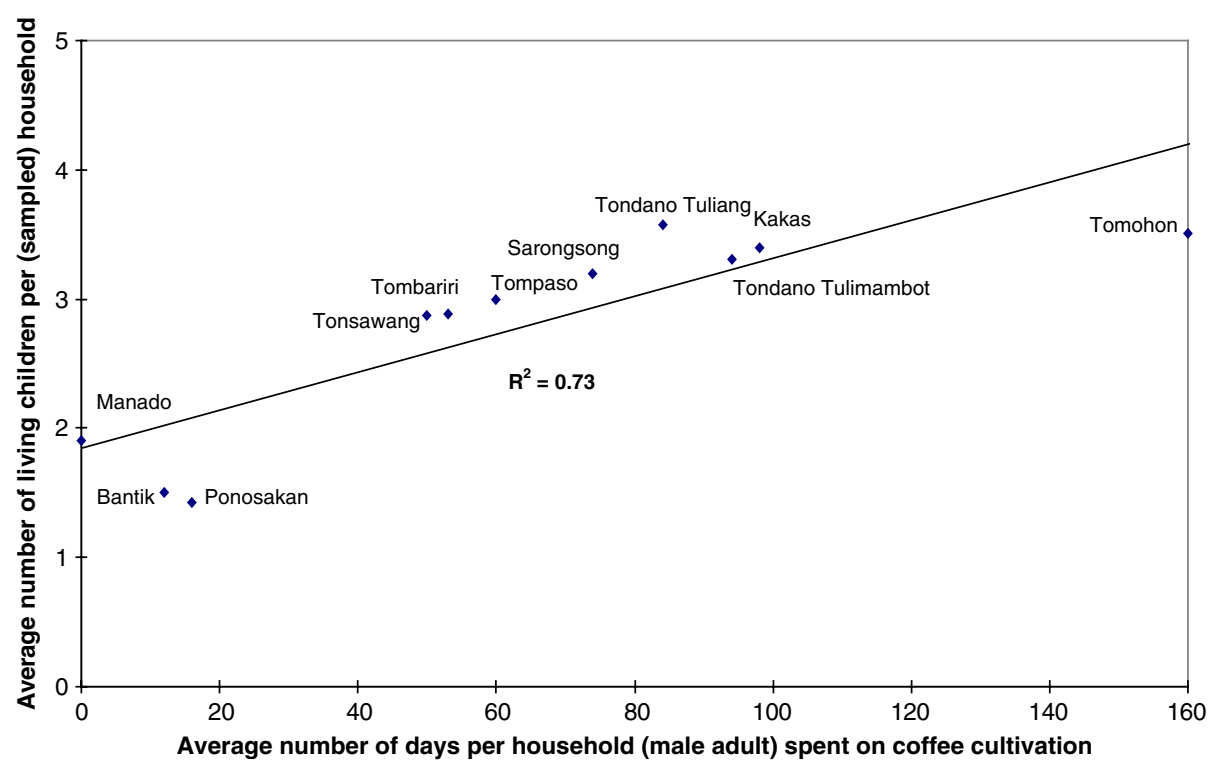

FIGURE 3

Household size and the labour burden of coffee cultivation in some Minahasan districts, 1874 (Henley 2005a, p. 394).

specific theory developed by Paul Alexander in the 1980s to explain that (then still unproven) association. In the Minahasan case, not only do we know that onerous cultivation services were associated with high birth rates, we also know that the typical duration of breast-feeding declined between the pre-colonial period and the late nineteenth century, and that this decline took place at least partly because of the involvement of mothers in compulsory labour. All elements of the Alexander model are in fact confirmed, except for one: there is no evidence from Minahasa for the practice of sexual abstinence during breast-feeding, which Alexander, and others (Santow 1987; Santow \& Bracher 1984), have seen as mediating between lactation and birth interval in the Javanese case. However, since the contraceptive effect of breast-feeding alone is strongly confirmed in the demographic literature (Aguirre et al. 1998; Saito 1996), this can be regarded as a minor incongruence.

\section{Wider Implications: Explaining 'Agricultural Involution'}

Does it really matter whether additional economic activity boosts fertility via the income which it supplies, or via the labour which it demands? In nineteenth-century Minahasa, labour demand and income supply exerted mutually independent influences on fertility because the demand for labour was maintained largely by political compulsion rather than by economic incentives. Under these circumstances it is possible that in some districts, as the Alexanders have argued for the whole of Java during the Cultivation System, rising fertility coincided with diminishing rather than rising incomes. Over the broad sweep of Indonesian history, however, this is no doubt the exception rather than the rule. 
The way in which the colonial state drove up export production in Java and Minahasa by political means, in the absence of commensurate economic incentives, was unusual even in the nineteenth-century context. In earlier periods the state was typically too weak to permit such exploits (Adas 1981; Reid 1998), and in the twentieth century it has seldom seen fit to attempt them. The normal motor of economic growth in Indonesia, up to quite recent times, has been the spontaneous production by small farmers, in response to market demand, of commercial crops and other products (Booth 1998, p. 237; Touwen 2001, pp. 315-327). Under these conditions labour demand and income supply went hand-in-hand, and the dynamics of demographic change had a broadly Malthusian character: where there was economic growth, population growth followed, and where the economy remained static or contracted, the population did likewise (Henley 2002, 2005b).

There is nevertheless a second circumstance, besides political pressure, under which labour demand might increase in the absence of income gains: population pressure, which might force farmers to adopt progressively more labour-intensive agricultural techniques in order to produce a greater amount of food from a fixed area of farmland. This is the process of demographically-driven agricultural intensification classically modelled by Boserup (1965). In Minahasa, population pressure played a role in a sustained expansion of the area under irrigation which began in the 1850s as an increasingly severe shortage of land forced farmers to replace swidden fields with laboriously-constructed and intensivelycultivated wet rice fields in order to maintain per capita food crop production (Henley 2005a, pp. 526, 587-590). In this situation, which is probably much less unusual in historical terms than that of compulsory export crop cultivation under state auspices, it is possible that a pernicious positive feedback loop could develop in which population growth leads via agricultural intensification to further labour demand, higher fertility, and hence continued population growth, all without proportionate income gains and with progressive impoverishment as a consequence.

The idea that wet rice cultivation as a system evokes, as well as absorbs, population growth (Reid 2001, p. 56), and does so in a way independent of changes in income, certainly helps to explain why, as Boomgaard (2007) has pointed out, by the early twentieth century many of Southeast Asia's old, densely populated, and once prosperous ricebowl areas had become notorious for their poverty. An example of this trajectory 'from riches to rags', as Boomgaard styles it, is the irrigated zone around Lake Tondano in Minahasa, which in the 1880s was probably the most prosperous part of Sulawesi (Hickson 1889, p. 214) but by the 1930s had become an enclave of 'poverty' and 'overpopulation' amid the affluence of the surrounding copra-producing districts (Brouwer 1936, p. 60; Kündig 1934, p. 188). On a much larger scale and over a much longer timespan, Lieberman (2003, pp. 51, 121, 176, 367-368, 420-421) has identified multiple cycles of overpopulation and impoverishment in Upper Burma and the Red River delta of North Vietnam. In this perspective the 'agricultural involution' of nineteenth-century Java, although indelibly associated by Geertz (1963) with the specificities of Dutch colonialism and the Cultivation System, becomes just one specimen of a recurrent historical phenomenon whereby the area and labour intensities of irrigated rice farming systems continue to increase, under the pressure of sustained population growth, long after the point of maximum labour efficiency has been passed, giving rise to intricately, expertly terraced and cultivated landscapes teeming with impoverished peasants and labourers.

Despite his neglect of the link between labour demand and fertility in the context of colonial labour services, Boomgaard proposes that one reason why wet rice cultivation 
eventually tends to impoverish the cultivators is that the labour burden which it imposes boosts fertility without raising incomes. The rise in fertility, he argues, occurs as a conscious response to the circumstance that irrigated farmers 'require more labour per household than swiddeners, because sawah cultivation is more labour-intensive than slash-and-burn per unit of product' (Boomgaard 2007, p. 195). Oshima (1987, p. 26) has expressed a similar view.

Since every additional rice producer is also a rice consumer, the logic of enlarging one's household deliberately in response to this kind of labour demand is in fact less obvious than it is in the case of compulsory labour services, which were usually allocated by household rather than on an individual basis. Indeed, the fact that high birth rates have led in this context to progressive impoverishment is itself a strong argument against any interpretation of the link between high fertility and wet rice agriculture in terms of a deliberate response to labour demand. It is true, as Geertz (1963, pp. 32-33) has famously observed, that in wet rice cultivation the marginal product of labour continues to be positive long after the average product (in this case, the average amount of rice produced per labourer) has started to decline - the best, and arguably the only, technical definition of agricultural involution (Figure 4). However, is it really likely that rice-growing households, faced with a problem of poverty caused by overpopulation and diminishing returns to labour, would try to solve it by having even more children to produce even less than the existing children, but to consume just as much?

The most credible explanation for the persistence of high fertility among wet rice cultivators despite declining labour productivity is, in my view, once again the unconscious one of reduced breast-feeding, and hence reduced birth intervals, as a consequence of heavy (or at least, extended) female labour. Certainly the shift from swidden to irrigated farming is not automatically accompanied, as Reid (1987, p. 40) has claimed it is, by a

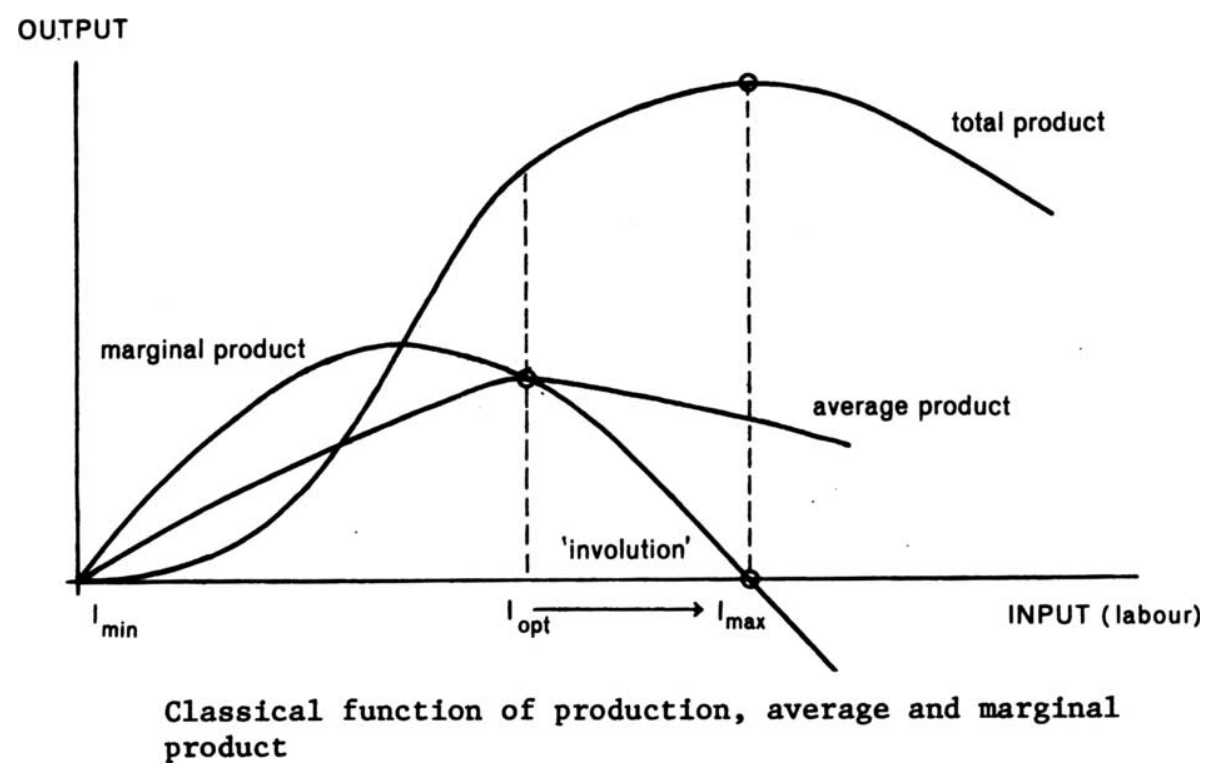

FIGURE 4

Involution defined in classical economic terms (Metzner 1982, p. 240). 
reduction in the female agricultural workload. In many parts of Java in the 1970s, at least half of the labour input in wet rice farming was provided by women and girls (White 1976, p. 158).

\section{Conclusion}

The theory that colonial taxation caused Indonesian women to have more babies by forcing them to breast-feed their existing babies less is at first sight far-fetched, and those who first proposed it did so partly for ideological reasons and without a shred of evidence to support it. Nevertheless according to the evidence presented earlier from nineteenthcentury Minahasa (which is the best evidence we have), that implausible theory appears to be correct. It is also an eminently useful theory - one that can help explain not only the paradox (Owen 1987) of rapid population growth without rapid economic growth or major public health improvements in nineteenth-century Java, but also the involutionary cycle of agricultural intensification, population growth and impoverishment which seems to be a recurrent feature of Southeast Asian history.

\section{REFERENCES}

ADAS, M. (1981) 'From avoidance to confrontation: peasant protest in precolonial and colonial Southeast Asia', Comparative Studies in Society and History, vol. 23, no. 2, pp. 217-247.

AGUIRRE, G. P., PALLONI, A. \& JONES, R. E. (1998) 'Effects of lactation on post-partum amenorrhoea: re-estimation using data from a longitudinal study in Guatemala', Population Studies, vol. 52, no. 2, pp. 231-248.

ALEXANDER, P. (1984) 'Women, labour and fertility: population growth in nineteenth century Java', Mankind, vol. 14, no. 5, pp. 361-371.

ALEXANDER, P. (1986) 'Labour expropriation and fertility: population growth in nineteenth century Java', in Culture and Reproduction: An Anthropological Critique of Demographic Transition Theory, ed. W. P. Handwerker, Westview Press, Boulder, CO, pp. 249-262.

ALEXANDER, J. \& ALEXANDER, P. (1979) 'Labour demands and the "involution" of Javanese agriculture', Social Analysis, vol. 3, pp. 22-44.

BOomgaARD, P. (1989) Children of the Colonial State: Population Growth and Economic Development in Java, 1795-1880, Free University Press, Amsterdam.

BOOMGAARD, P. (2007) 'From riches to rags? Rice production and trade in Asia, particularly Indonesia, 1500-1950', in A History of Natural Resources in Asia: The Wealth of Nature, eds G. Bankoff \& P. Boomgaard, Palgrave Macmillan, Houndmills, Basingstoke, pp. 185-203. воотн, А. (1998) The Indonesian Economy in the Nineteenth and Twentieth Centuries: A History of Missed Opportunities, Macmillan, Houndmills, Basingstoke.

BOSERUP, E. (1965) The Conditions of Agricultural Growth: The Economics of Agrarian Change under Population Pressure, George Allen and Unwin, London.

BROUWER, M. (1936) Bestuursvormen en Bestuursstelsels in de Minahassa [Forms and Systems of Government in Minahasa], H. Veenman, Wageningen.

DE CLERCQ, F. S. A. (1870) 'Boekaankondiging [Book announcement]', Tijdschrift voor Nederlandsch Indië, 1870, pp. 124-137.

DE CLERCQ, F. S. A. (1891) 'De hervorming van het Minahasa-stelsel [Reform of the Minahasa system]', Indisch Genootschap: Verslagen der Algemeene Vergaderingen, 1891, pp. 203-231. 
DE LANGE, S. H. (1897) 'Menado en Kema als vrijhaven [Manado and Kema as free ports]', Tijdschrift voor Nederlandsch Indië, 1897, pp. 667-707.

EDELING, A. C. J. (1875) Memorie Omtrent de Minahasa, 13-8-1875 [Report on Minahasa, 13-8-1875], Nationaal Archief (The Hague), Ministerie van Koloniën Verbaal 17-4-1877/20. Unpublished document.

FRANCIS, E. (1860) Herinneringen uit den Levensloop van een' Indisch' Ambtenaar van 1815 tot 1851 [Recollections of the Career of an Indies Ambtenaar from 1815 to 1851], vol. 3, H. M. van Dorp, Batavia.

GEERTZ, C. (1963) Agricultural Involution: The Process of Ecological Change in Indonesia, University of California Press, Berkeley, CA.

GRAAFLAND, N. (1867-1869) De Minahassa. Haar Verleden en haar Tegenwoordige Toestand [Minahasa. Past and Present], two volumes, M. Wijt, Rotterdam.

GRAAFLAND, N. (1898) De Minahassa. Haar Verleden en haar Tegenwoordige Toestand, 2nd edn, two volumes, G. Kolff, Batavia.

HENLEY, D. (2002) 'Population, economy and environment in island Southeast Asia: an historical view with special reference to northern Sulawesi', Singapore Journal of Tropical Geography, vol. 23, no. 2, pp. 167-206.

HENLEY, D. (2005a) Fertility, Food and Fever: Population, Economy and Environment in North and Central Sulawesi 1600-1930, KITLV Press, Leiden.

HENLEY, D. (2005b) 'Population and the means of subsistence: explaining the historical demography of island Southeast Asia, with particular reference to Sulawesi', Journal of Southeast Asian Studies, vol. 36, no. 3, pp. 337-372.

HENLEY, D. (2006) 'From low to high fertility in Sulawesi (Indonesia) during the colonial period: explaining the "first fertility transition"', Population Studies, vol. 60, no. 3, pp. 309-327.

HICKSON, S. J. (1889) A Naturalist in North Celebes: A Narrative of Travels in Minahassa, the Sangir and Talaut Islands, with Notices of the Fauna, Flora and Ethnology of the Districts Visited, John Murray, London.

HULL, T. H. (2001) 'Indonesian fertility behaviour before the transition: searching for hints in the historical record', in Asian Population History, eds T.-J. Liu, J. Lee, D. S. Reher, O. Saito \& F. Wang, Oxford University Press, Oxford, pp. 152-175.

JANSEN, A. J. F. (1861) ‘De landbouw in de Minahasa van Menado, in 1853 [Agriculture in Minahasa (Manado), in 1853]', Tijdschrift voor de Taal-, Land- en Volkenkunde van Nederlandsch-Indië, vol. 10, pp. 221-258.

KÜNDIG, A. (1934) 'Eenige statistische gegevens uit de Minahasa [Some statistics from Minahasa]', Mededeelingen van den Dienst der Volksgezondheid in Nederlandsch-Indië, vol. 23, pp. 167-194.

LIEBerman, V. (2003) Strange Parallels: Southeast Asia in Global Context, c. 800-1830. Volume 1: Integration on the Mainland, Cambridge University Press, Cambridge.

MalthuS, T. R. (1976) An Essay on the Principle of Population, 1798, W. W. Norton, New York. METZNER, J. K. (1982) Agriculture and Population Pressure in Sikka, Isle of Flores: A Contribution to the Study of the Stability of Agricultural Systems in the Wet and Dry Tropics, The Australian National University, Canberra.

OSHIMA, H. T. (1987) Economic Growth in Monsoon Asia: A Comparative Survey, University of Tokyo Press, Tokyo.

OWEN, N. G. (1987) 'The paradox of nineteenth-century population growth in Southeast Asia: evidence from Java and the Philippines', Journal of Southeast Asian Studies, vol. 18, no. 1, pp. $45-57$. 
PADTBRUGGE, R. (1866) 'Beschrijving der zeden en gewoonten van de bewoners der Minahassa [Description of the manners and customs of the inhabitants of Minahasa]', Bijdragen tot de Taal-, Land- en Volkenkunde van Nederlandsch-Indië, vol. 13, pp. 304-331.

[QUARLES VAN UFFORD, H.] (1856) Aanteekeningen Betreffende eene Reis door de Molukken van Zijne Excellentie den Gouverneur-Generaal Mr A.J. Duymaer van Twist, in de Maanden September en October 1855 [Notes on a Journey through the Moluccas by His Excellency Governor-General A.J. Duymaer van Twist, in the Months of September and October 1855], Martinus Nijhoff's Gravenhage.

RAFFLES, T. S. (1978) The History of Java, two volumes, Oxford University Press, Kuala Lumpur (originally published 1817).

REID, A. (1987) 'Low population growth and its causes in pre-colonial Southeast Asia', in Death and Disease in Southeast Asia: Explorations in Social, Medical and Demographic History, ed. N. G. Owen, Oxford University Press, Singapore, pp. 33-47.

REID, A. (1998) 'Political "tradition" in Indonesia: the one and the many', Asian Studies Review, vol. 22, no. 1, pp. 23-38.

REID, A. (2001) 'South-east Asian population history and the colonial impact', in Asian Population History, eds T.-J. Liu, J. Lee, D. S. Reher, O. Saito \& F. Wang, Oxford University Press, Oxford, pp. 45-62.

SAITO, O. (1996) 'Historical demography: achievements and prospects', Population Studies, vol. 50, no. 3, pp. 537-553.

SANTOW, G. (1987) 'Reassessing the contraceptive effect of breastfeeding', Population Studies, vol. 41 , no. 1 , pp. 147-160.

SANTOW, G. \& BRACHER, M. D. (1984) 'Child death and time to the next birth in Central Java', Population Studies, vol. 38, no. 2, pp. 241-253.

SMITH, A. (1976) An Inquiry into the Nature and Causes of the Wealth of Nations, eds R. H. Campbell \& A. S. Skinner, Oxford University Press, Oxford (originally published 1776).

TOUWEN, J. (2001) Extremes in the Archipelago: Trade and Economic Development in the Outer Islands of Indonesia, 1900-1942, KITLV Press, Leiden.

WALLACE, A. R. (1987) The Malay Archipelago: The Land of the Orang-utan and the Bird of Paradise: A Narrative of Travel, with Studies of Man and Nature, facsimile of the 10th edn, Graham Brash, Singapore (originally published 1890).

WESSELS, L. (1891) 'De gouvernments-koffiecultuur in de Minahassa, residentie Menado [Government coffee cultivation in Minahasa (residency of Manado)]', Tijdschrift voor Nederlandsch Indië, vol. 20, no. 1, pp. 50-71, 123-146.

WHITE, B. (1973) 'Demand for labor and population growth in colonial Java', Human Ecology, vol. 1, no. 3, pp. 217-236.

WHITE, B. (1976) Production and Reproduction in a Javanese Village, PhD Thesis, Columbia University, New York.

David Henley (author to whom correspondence should be addressed), Royal Netherlands Institute of Southeast Asian and Caribbean Studies (KITLV), Reuvensplaats 2, PO Box 9515, 2300 RA Leiden, The Netherlands. Tel: +31 71 5272295; Fax: +31 715272638. E-mail: henley@kitlv.nl; d.e.f.henley@hum.leidenuniv.nl 